\title{
PENGEMBANGAN BUKU PEDOMAN MANAJEMEN TEAMWORK DALAM UPAYA PENINGKATAN MUTU DI MTS. AT-TAHRIRIYAH PANGPAJUNG MODUNG BANGKALAN
}

\author{
Abdul Jalil \\ Sri Setyowati \\ Warih Handayaningrum \\ Pascasarjana Manajemen Pendidikan Universitas Negeri Surabaya \\ abduljalil@mhs.unesa.ac.id
}

\begin{abstract}
Abstrak: Mutu telah menjadi concern untama dalam setiap perbincangan tentang produk atau layanan, sehingga pengelolaannya menjadi fokus penting untuk diimplementasikan pada hampir semua organisasi termasuk sekolah atau lembaga pendidikan. Banyak sekali hal yang mempengaruhi mutu sekolah di antaranya adalah adanya kerja sama tim dalam mencapai tujuan sebagaimana tercantum dalam visi, misi, dan program sekolah. Oleh sebab itu, perlu adanya buku panduan yang mendeskripsikan tentang fungsi dan tugas teamwork tersebut sehingga efektivitas kinerjanya lebih baik. Penelitian ini merupakan research and development (R\&D). Adapun model pengembangan Buku Pedoman manajemen teamwork MTs. At-Tahririyah Pangpajung Modung yang digunakan adalah 4-D yang dikemukakan oleh Thiagarajan yang telah dimodifikasi menjadi 3-D yaitu define (mendefinisikan), design (merancang) dan develop (mengembangkan). Teknik pengumpulan data menggunakan metode observasi, dokumentasi dan angket sedangkan teknik analisis datanya menggunakan analisis deskriftif kualitatif dan kuantitatif. Adapun teknik pengukuran datanya menggunakan skala linkert. Pada uji coba efektivitas buku pedoman manajemen teamwork menggunakan desain before-after untuk menguji perbedaan sebelum dan sesudah perlakuan kemudian uji signifikansinya menggunakan uji-t. Hasil penelitian menunjukkan bahwa: (1) proses pengembangan buku pedoman manajemen teamwork MTs. At-tahririyah Pangpajung Modung Bangkalan melalui tiga proses tahapan sesuai dengan Four-D yang sudah dimodifikasi menjadi 3-D. (2) Hasil materi/isi bahasa memperoleh skor 179 dengan persentase $92 \%$ yang berarti buku pedoman sudah baik dan layak digunakan. Sedangkan pada aspek kebahasaan mendapatkan skor 45 dengan persentase $82 \%$ yang berarti baik dan layak untuk diimplementasikan. (3) Sedangkan hasil uji coba buku pedoman menunjukkan bahwa ada perbedaan hasil pre-test dan post-test dengan nilai $r$ 0,56 yang menunjukkan bahwa penggunaan buku pedoman mempengaruhi efektiitas kinerja teamwork sebesar $56 \%$. Sedangkan nilai signifikansinya sebesar 0,00 yang artinya nilai tersebut $<0,05$, sehingga dapat disimpulkan bahwa penggunaan buku pedoman manajemen teamwork dapat meningkatkan efektivitas kinerja teamwork MTs. At-Tahririyah Pangpajung Modung Bangkalan.
\end{abstract}

Kata kunci: buku pedoman, imbalan sosial, komitmen guru, dan kinerja guru

Abstract :Quality has always become a main concern in every discussion of product and public service, so that its management has extremelly become an important implementation focus in all organization including school or education institution as well. There are many important things influenced the school quality such as teamwork to achieve some school's goals as implied at vision, mission and program. Therefore, it's really important to have a handbook to describe the main function and teamwork assigment so it's existence is getting better and better. This research is a research and development (R\&D), while the development model of the handbook of teamwork management at AtTahririyah Islamic Secondary School used 4-D, promoted by Thiagarajan , which has been modified into 3-D, define, design and develop. Data was collected by observation, documentation, and questionnaire while data analysis technique were analyzed and developed by qualitative descriptive and quantitative. Then data measurement technique used was Linkert scale. While in examining the effectiveness of the guidance book, before-after design was used to find out the difference of before and after test then using t-test to know degree of significant. The result of research shows that: (1) the development process of handbook of teamwork management at At-Tahririyah Islamic Secondary School passed through three processes as Four-D models, being modified into Three-D models, (2) 
The result of material/conetns' validity got 179 , with $92 \%$. It means that the handbookis very good and ready-tested while The result of language validity got 45 , with $82 \%$. It means that the handbookis very good and ready-tested linguistically. (3) The result of the limited test reflects that there is a difference result between pre-tes and post-test score with $r$ score 0,56 which shows that the use of handbookinluence $56 \%$ to the effectiveness of teamwork job. While the significant score is 0,00 , means that score $<0,05$. In conclusion, based on the research the use of handbookcould increase the effectiveness of teamwork task at At-Tahririyah Islamic Secondary School Pangpajung Modung Bangkalan..

Keywords: Teamwork, increasement of quality

Beberapa orang berpendapat bahwasanya mutu dianggap sebagai suatu hal yang membingungkan dan sulit untuk diukur. Menurut Peters \& Austin (Sallis, 2010 p. 29), "mutu adalah sebuah hal yang berhubungan dengan gairah dan harga diri". Menurut Sallis (2010, p.56),"mutu dapat didefinisikan sebagai sesuatu yang memuaskan dan melampaui kebutuhan pelanggan". Tentu pada konteks pendidikan,pelanggan yang dimaksudkan adalah peserta didik sebagai pelanggan internal dan masyarakat sebagai pelanggan eksternal.

Di samping itu, bentuk manajemen pendidikan sangat berpengaruh tehadap pencapaian mutu atau kualitas pendidikan menutut Rivai \& Murni (2009, p.63)," pada saat ini pendidikan nasional masih dihadapkan oleh beberapapermasalahan yang menonjol: (1) masih rendahnya pemerataan memperoleh pendidikan; $\quad$ (2) masih rendahnya mutu dan relevansi pendidikan; dan (3) masih lemahnya manajemen pendidikan". Keunggulan adalah merupakan daya saing lembaga pendidikan untuk selalu kompetitif di dunia pendidikan. Salah satunya melalui pencapaian kualitas produk yang memiliki kualitas unggulan dan mampu memuaskan pelanggan dengan segala atribut yang diinginkan pelanggan. Namun pada kenyataannya masih banyak institusi pendidikan yang belum memiliki manajemen yang bagus dalam pengelolaan pendidikannya. Manajemen yang digunakan masih konvensional, sehingga kurang bisa menjawab tantangan zaman dan terkesan tertinggal dari modernitas.

Imbalan sosial berupa: (1) simbol status, (2) pujian dan pengakuan, (3) kenyamanan tugas, (4) dan persahabatan. Kedua bentuk kompensasi non finansial tersebut akan digunakan sebagai variabel dalam penelitian ini.
"Tim merupakan sekelompok orang yang memiliki tujuan bersama" (Tjiptono \& Diana, 2003, p.165). "Tim merupakan kumpulan individu yang memiliki perbedaan kepribadian, ide, kekuatan, kelemahan, tingkat antusiasme, dan kebutuhan terhadap kerjanya" (Sallis, 2010, p. 183). Tjiptono \& Diana (2003, p. 166) juga menambahkan pendapatnya sebagai berikut: Dalam hal ini tidak semua kumpulan orang dapat dikatakan sebagai tim. Sekumpulan orang tertentu dapat dianggap sebagai tim atau kelompok kerja maka sekumpulan orang tersebut harus memiliki beberapa karakteristik tertentu diantaranya; ada kesepakatan terhadap misi tim, semua anggota mentaati peraturan tim yang berlaku, ada pembagian tanggungjawab yang adil, dan setiap anggota tim yang beradaptasi terhadap perubahan.

Sallis (Syafaruddin, 2002, p.71) berpendapat bahwa suatu tim adalah kumpulan orang-orang yang bekerja dengan program yang sama. Tim kerja pada setiap organisasi merupakan komponen utama dalam pelaksanaan manajemen mutu terpadu untuk membangun kepercayaan, memperbaiki komunikasi, dan mengembangkan kemandirian.

Menurut Oakland (Sallis, 2010, p.179),"kerja tim dalam sebuah organisasi merupakan komponen penting dari upaya peningkatan mutu. Mengingat kerja tim akan meningkatkan kepercayaan diri, komunikasi, dan mengembangkan kemandirian". Menurut Crosby (Sallis, 2010, p. 183) "Menjadi bagian dari sebuah tim bukanlah fungsi alami manusia; hal itu harus dipelajari". Maka dari itu teamwork yang kuat akan menghasilkan suatu sinergi kerja diantara semua komponen atau personel sekolah yang bekerja sama dalam bidang akademik maupun non akademik. Timpe (Syafaruddin, 2002, p. 71) menyampaikan pendapatnya sebagai berikut: 
Teori psikologi menegaskan bahwa kelompok dengan semangat tim yang tinggi bekerja lebih baik daripada kelompok yang hanya memiliki sedikit semangat tim. Teori ini juga menunjukkan bahwa para individu bila ditempatkan pada posisi sentral dalam kelompok, akan bekerja lebih baik sebagai bagian kelompok daripada mereka bekerja sendirian.

Kerjasama tim merupakan salah satu fundamental dalam peningkatan mutu. Menurut Fandy\& Diana (2003,p.165) faktor-faktor yang mendasari perlunya dibentuk tim-tim tertentu dalam suatu organisasi adalah (1) pemikiran dari 2 (dua) orang atau lebih cenderung lebih baik daripada pemikiran satu orang, (2) Konsep dari $(1+1>2)$, yaitu bahwa hasil keseluruhan (tim) jauh lebih baik daripada jumlah bagiannya anggota individual, (3) Anggota tim dapat saling mengenal dan saling percaya, sehingga mereka dapat saling membantu, (4) kerja sama tim dapat menyebabkan komunikasi terbina dengan baik.

Kriteria untuk efektivitas tim kerja atau teamwork adaah performance dan viability. Secara konseptual, performance atau kinerja mudah diukur dari sampai di mana tim dapat menyelesaikan pekerjaan. Kriteria viability lebih tidak kentara dan mudah diabaikan. Team viability menunjukkan kepuasan anggota tin dan melanjutkan keinginan untuk memberikan kontribusi. Teamwork tidak efektif apabila dapat menyelesaikan pekerjaan, tetapi merusak diri dan mengorbankan orang dalam proses.

Teamwork untuk menjadi efektif juga memerlukan team-friendly organization. Teamwork memerlukan sistem dukungan. Mereka mendapat kesempatan sukses apabila dipelihara dan difasilitasi oleh organisasi. Maksud tim perlu selaras dengan strategi organisasi. Demikian juga, partisipasi tim dan otonomi memerlukan budaya organisasi yang menghargai proses tersebut. Anggota tim perlu peralatan teknologi yang tepat, skedul yang beralasan dan pelatihan. Tim kerja juga perlu dihargai oleh sistem reward organisasi.

Buku sebagai bahan tertulis merupakan suatu buku yang berisi suatu ilmu pengetahuan hasil analisis terhadap kurikulum dalam bentuk suatu tulisan. Adapun kriteria buku yang baik adalah buku yang ditulis dengan menggunakan bahasa yang baik dan mudah dimengerti, disajikan secara menarik, isi buku juga menggambarkan sesuatu yang sesuai dengan ide penulisnya (Depdiknas, 2008, p.12).

Buku Pedoman manajemen teamwork ini adalah buku tulisan yang berisi panduan manajerial teamwork dalam melaksanakan kinerjanya berdasarkan tugas dan fungsi pokoknya. Hal yang menjadi fokus dari isi buku pedoman ini pada intinya ingin menempatkan teamwork sesuai dengan kapabilitas serta latar belakang pendidikannya sehingga efektivitas kinerja benar-benar dapat dilakukan dengan baik untuk memajukan segala bentuk program, visi dan misi MTs. At-tahririyah Pangpajung Modung Bangkalan.

Penyusunan bahan ajar cetak, khusunya buku, dijelaskan dalam Depdiknas (2008, p. 19) bahwa sebuah buku akan dimulai dari latar belakang penulisan, definisi/ pengertian dari judul yang dikemukakan, penjelasan ruang lingkup bahasan dalam buku, hukum dan aturan yang dibahas, contoh-contoh yang diperlukan, data dan interpretasi berbagai argumen yang sesuai. Namun pada buku pedoman yang akan dibuat akan ditambahkan penjelasan tentang bagaimana mengefektifkan kinerja teamwork serta penilaian kinerja teamwork sehingga madrasah lebih mudah untuk melakukan langkah evaluatif.

\section{METODE}

Metode penelitian dan pengembangan (R\&D) adalah metode penelitian yang digunakan untuk menghasilkan rancangan produk baru, menguji keefektifan produk yang telah ada, serta mengembangkan dan mencipatakan produk baru. Bila produk baru telah teruji, maka produk tersebut bila digunakan dalam pekerjaan akan lebih mudah, lebih cepat, kuantitas dan kualitas produk hasil kerja akan meningkat.

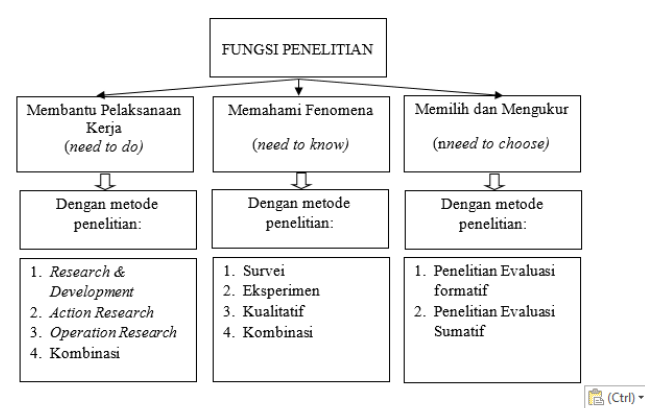

Gambar 3.1 Bagan Fungsi Penelitian Sumber Sugiyono,2015, p.27

Beradasarkan gambar di atas terlihat bahwa metode penelitian dan pengembangan 
(research and development) merupakan salah satu jenis penelitian yang berfungsi untuk membantu pelaksaan kerja (need to do). Penelitian dan pengembangan merupakan proses/metode yang digunakan untuk memvalidasi dan mengembnagkan produk. Yang dimaksud produk disisi tidak hanya suatu yang berupa benda seperti buku teks, film untuk pembelajaran, dan software (perangkat lunak) komputer, tetapi juga seperti metode mengajar,dan program seperti program pendidikan dalam upaya peningkatan dan perbaikan kualitas pendidikan.

Buku yang akan dikembangkan dalam penelitian ini adalah merupakan buku pedoman yang berisi tentang teknis-teknis pengembangan teamwork di MTs. At-tahririyah Pangpajung Modung Bangkalan. Model pengembangan buku pedoman teamwork dalam penelitian ini mengacu pada model 4-D (four- $D$ models) menurut Thiagarajan. Model ini terdiri dari 4 tahap pengembangan, yaitu Define, Design, Develop, dan Deseminate (Pendefinisian, pendataan, perancangan, pengembangan, pengembangan, dan penyebaran). Dengan model four- $D$ ini dimaksudkan agar model tersebut dapat diimplementasikan dalam penelitian, sesuai karakteristik penelitian dengan mempertimbangkan tujuan penelitian, karaktersitik produk, serta terbatasnya waktu penelitian.

Pemilihan model Thiagarajan (four-D Model) yang sesuai kebutuhan penelitian ini didasarkan atas pertimbangan bahwa model ini sesuai karakteristik penelitian pengembangan buku pedoman teamwork. Pada penelitian ini, karena terbatasnya waktu, maka pelaksanaan langkah model tersebut hanya dibatasi sampai pada uji coba produk.

Adapun teknik analisis data yang dilakukan dalam penelitian pengembangan in adalah teknik analisis deskriftif dan kuantitatif. Data berupa masukan, komentar, kritik dan saran dianalisis secara kualitatif. Data kualitatif dipaparkan pada kesimpulan hasil angket dari validasi para ahli tentang kelayakan buku pedoman sebagai bahan pertimbangan untuk melakukan revisi dan penyempurnaan buku pedoman manajemen teamwork. Sedangkan data kuantitatif dianalisis dengan menggunakan penyekoran. Teknik pengukuran menggunakan skala linkert, untuk mengukur sikap, pendapat dan persepsi seseorang atau kelompok (Sugiyono, 2010).
Untuk menguji efektivitas buku pedoman manajemen teamwork, peneliti menggunakan desain "before-after" yaitu desain penelitian dengan cara membandingkan keadaan sebelum-sesudah perlakuan (Sugiono, 2010) dengan gambar sebagai berikut:

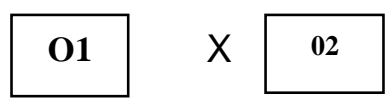

Gambar 2.4 Desain Eksperimen (Before-after) untuk menguji $\mathrm{O} 1$ nilai sebelum perlakuan $\mathrm{O} 2$ nilai sesudah perlakuan

\section{HASIL DAN PEMBAHASAN}

Proses pengembangan buku pedoman manajemen Teamwork di MTs. At-Tahririyah Pangpajung Modung Bangkalan ini menggunakan Four-D Models, Model pengambangan ini terdiri dari empat tahap: (a) define, (b) desain, (c) develop, (d) disseminate. Dalam pelaksanaan penelitian ini pengembangan buku pedoman manajemen teamwork ini hanya dilaksanakan sampai pada tahap ketiga, yaitu (a) define/tahap pendefinisian, (b) design/ tahap perancangan, dan (c) develop/tahap pengembangan atau diadaptasi peneliti menjadi 3-D.

Setelah pemeriksaan model pengukuran terpenuhi, maka selanjutnya adalah pemeriksaan terhadap model Kualitas buku pedoman manajemen teamwork sebagai buku pedoman penunjang kinerja teamwork di MTs. At-Tahririyah Pangpajung Modung Bangkalan dikembangkan menjadi 3 sub masalah, yaitu kevalidan, kepraktisan dan keefektifan buku pedoman.

Untuk mengetahui kevalidan buku pedoman dapat diketahui dari hasil validasi oleh para pakar/ahli dan praktisi. Berikut hasil sajian validasi buku pedoman manajemen teamwork di MTs. At-Tahririyah Pangpajung Modung Bangkalan.

Tujuan tahap pengembangan ini adalah menghasilkan bentuk akhir buku pedoman manajemen teamwork setelah melalui revisi berdasarkan masukan para ahli/praktisi dan data hasil uji coba. Tahap pengembangan ini meliputi langkah-langkah sebagai berikut:

\section{Kevalidan materi yang dikembangkan}

Penilaian para ahli/praktisi terhadap buku pedoman manajemen teamwork MTs. At- 
Tahririyah Pangpajung Modung Bangkalan mencakup: Bahasa, MSDM dan isi materi. Berdasarkan masukan para ahli, materi pembelajaran direvisi untuk membuatnya lebih tepat, efektif, mudah digunakan dan memiliki kualitas teknik yang tinggi. Dalam pengembangan buku pedoman ini akan divalidasi oleh lima ahli diantaranya adalah:

Buku pedoman manajemen teamwork MTs. At-Tahririyah Pangpajung Modung Bangkalan ini divalidasi oleh tiga validator (ahli bidang MSDM). Hasil validasi kedua validator terhadap buku pedoman manajemen teamwork ini dijabarkan berdasarkan 5 (lima) komponen yaitu kelengkapan materi, kedalaman materi, keakuratan materi, materi pendukung dan kesesuaian materi. Pengembangan buku pedoman manajemen teamwork MTs. AtTahririyah Pangpajung Modung Bangkalan ini divalidasi

\begin{tabular}{|c|c|c|c|c|c|c|c|c|}
\hline \multirow[t]{2}{*}{ No } & \multirow[t]{2}{*}{ Komponen } & \multirow[t]{2}{*}{ Indikator } & \multicolumn{3}{|c|}{$\begin{array}{c}\text { Skala } \\
\text { Penialaian } \\
\text { Validasi I }\end{array}$} & \multicolumn{3}{|c|}{$\begin{array}{c}\text { Skala } \\
\text { Penilaian } \\
\text { Validasi II }\end{array}$} \\
\hline & & & v1 & v2 & v3 & vl & V2 & v3 \\
\hline 1 & & $\begin{array}{l}\text { Ketepatan Materi dengan } \\
\text { tujuan teamwork dalam } \\
\text { implementasi TQM }\end{array}$ & 4 & 3 & 4 & 5 & 4 & 5 \\
\hline 2 & Ketepatan & $\begin{array}{l}\text { Kesesuaian langkah-langah } \\
\text { proses rekrutmen } \\
\text { teamwork dengan tugas } \\
\text { dan fungsi pokoknya }\end{array}$ & 4 & 4 & 4 & 5 & 5 & 4 \\
\hline 3 & Materi & $\begin{array}{l}\text { Kesuaian uraian tugas } \\
\text { teamwork dengan tugas } \\
\text { dan fungsi pokoknya. }\end{array}$ & 4 & 4 & 3 & 4 & 5 & 5 \\
\hline \multirow[t]{4}{*}{4} & & $\begin{array}{l}\text { Relevansi materi dengan } \\
\text { kebutuhan dan konsep } \\
\text { dasar manajemen }\end{array}$ & 4 & 3 & 4 & 5 & 4 & 4 \\
\hline & Jumlah nilai & & 16 & 14 & 15 & 19 & 18 & 18 \\
\hline & \multicolumn{2}{|c|}{ Jumlah Nilai Maksimal } & 20 & 20 & 20 & 20 & 20 & 20 \\
\hline & \multicolumn{2}{|l|}{ Persentase } & $\begin{array}{l}80 \\
\%\end{array}$ & $\begin{array}{l}70 \\
\%\end{array}$ & $\begin{array}{l}75 \\
\%\end{array}$ & $\begin{array}{l}95 \\
\%\end{array}$ & $\begin{array}{l}90 \\
\%\end{array}$ & $\begin{array}{l}90 \\
\%\end{array}$ \\
\hline
\end{tabular}

Tabel. 4.1. Uraian Validator Mater

\begin{tabular}{|c|c|c|c|c|c|c|c|c|}
\hline \multirow[t]{2}{*}{ No } & \multirow[t]{2}{*}{ Komponen } & \multirow[t]{2}{*}{ Indikator } & \multicolumn{3}{|c|}{$\begin{array}{c}\text { Skala } \\
\text { Penialaian } \\
\text { Validasi I }\end{array}$} & \multicolumn{3}{|c|}{$\begin{array}{l}\text { Skala } \\
\text { Penilaian } \\
\text { Validasi II }\end{array}$} \\
\hline & & & v1 & v2 & v3 & vl & v2 & $v^{3}$ \\
\hline 1 & \multirow{4}{*}{$\begin{array}{c}\text { Ketepatan } \\
\text { Materi }\end{array}$} & $\begin{array}{l}\text { Ketepatan Materi dengan } \\
\text { tujuan teamwork dalam } \\
\text { implementasi TQM }\end{array}$ & 4 & 3 & 4 & 5 & 4 & 5 \\
\hline 2 & & $\begin{array}{l}\text { Kesesuaian langkah-langah } \\
\text { proses rekrutmen } \\
\text { teamwork dengan tugas } \\
\text { dan fungsi pokoknya }\end{array}$ & 4 & 4 & 4 & 5 & 5 & 4 \\
\hline 3 & & $\begin{array}{l}\text { Kesuaian uraian tugas } \\
\text { teamwork dengan tugas } \\
\text { dan fungsi pokoknya. }\end{array}$ & 4 & 4 & 3 & 4 & 5 & 5 \\
\hline 4 & & $\begin{array}{l}\text { Relevansi materi dengan } \\
\text { kebutuhan dan konsep } \\
\text { dasar manajemen }\end{array}$ & 4 & 3 & 4 & 5 & 4 & 4 \\
\hline & Jumlah nilai & & 16 & 14 & 15 & 19 & 18 & 18 \\
\hline & Jumlah Nilai & aksimal & 20 & 20 & 20 & 20 & 20 & 20 \\
\hline & Persentase & & 80 & 70 & 75 & 95 & 90 & 90 \\
\hline
\end{tabular}

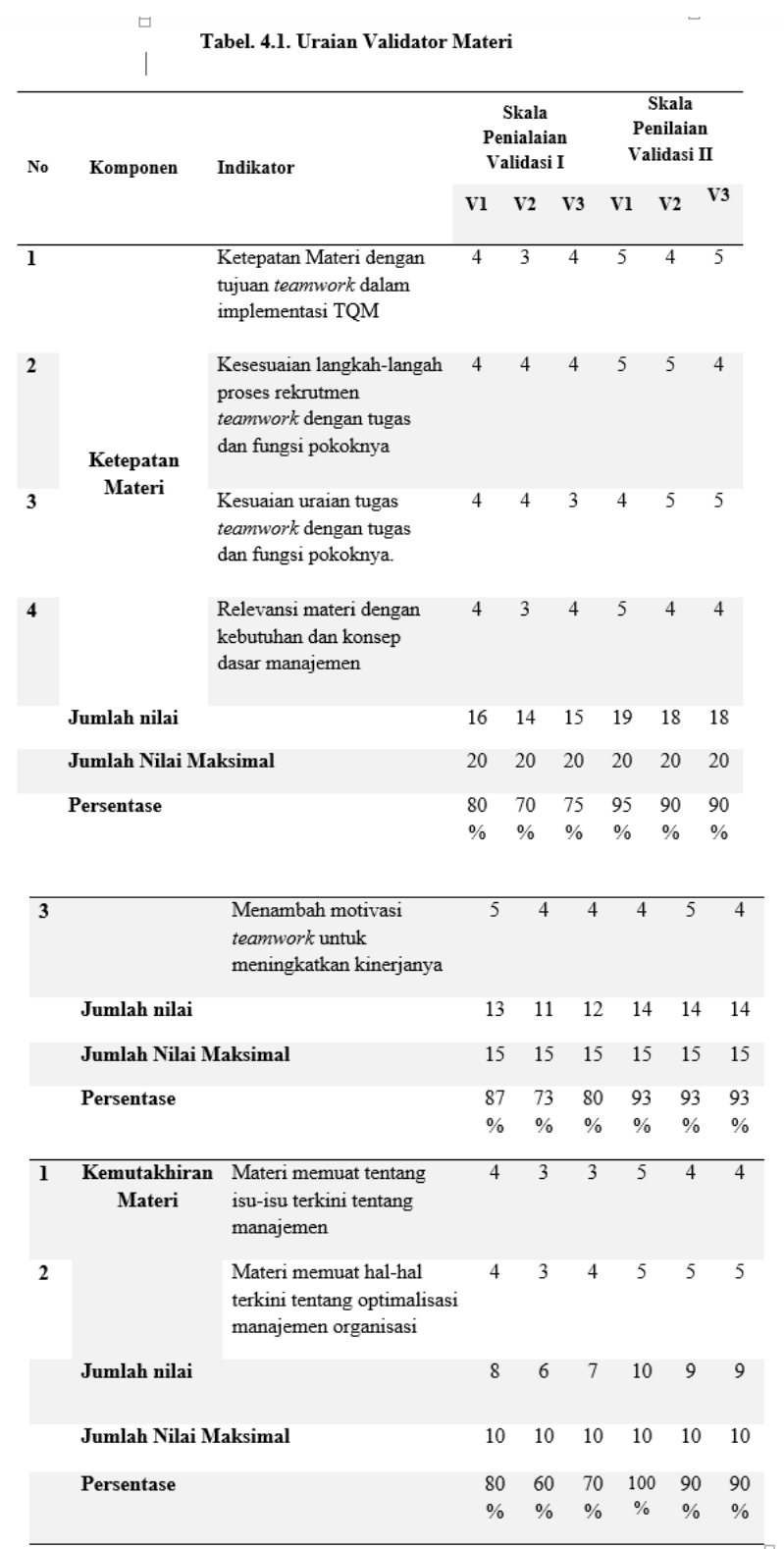

Tabel 4.3. Kriteria Persentase Validasi Materi Komponen Ketepatan Materi

\begin{tabular}{llc}
\hline \multicolumn{1}{c}{ Keterangan Angket } & \multicolumn{1}{c}{ Makna Keterangan } & Persentase Skor Kriterium \\
\hline Sangat Baik & Dapat digunakan & $81 \%-100 \%$ \\
\hline Baik & Layak dan perlu revisi & $61 \%-80 \%$ \\
\hline Cukup Baik & $\begin{array}{l}\text { Cukup layak dan perlu } \\
\text { revisi }\end{array}$ & $41 \%-60 \%$ \\
\hline Kurang Baik & $\begin{array}{l}\text { Kurang layak dan revisi } \\
\text { besar }\end{array}$ & $21 \%-40 \%$ \\
\hline Tidak Baik & \begin{tabular}{l} 
Tidak layak \\
\hline
\end{tabular} & $0 \%-20 \%$ \\
\hline
\end{tabular}


Dari tabel di atas, kita dapat mengetahui bahwa buku pedoman manajemen teamwork MTs. At-Tahririyah Pangpajung Modung Bangkalan pada komponen ketepatan materi hasil skor validasi I adalah 45 dengan presentase $75 \%$ yang berati baik, layak dan perlu direvisi. Validasi II pada komponen kelengkapan materi memperoleh skor 55 dengan presentase $91 \%$ yang berarti sangat baik, sangat layak, dan tidak perlu direvisi.

\begin{tabular}{|c|c|c|c|c|}
\hline No & Komponen & Indikator & $\begin{array}{c}\text { Skala } \\
\text { Validasi } 1\end{array}$ & $\begin{array}{c}\text { Skala } \\
\text { Validasi } 2\end{array}$ \\
\hline 1 & & $\begin{array}{l}\text { Judul buku pedoman } \\
\text { merepresentasikan isi dan } \\
\text { materi secara keseluruhan }\end{array}$ & 4 & 4 \\
\hline 2 & $\begin{array}{c}\text { Teknik } \\
\text { Penyajian }\end{array}$ & $\begin{array}{l}\text { Penyajian materi dalam } \\
\text { buku pedoman runtut dan } \\
\text { dapat mengarahkan } \\
\text { pemahaman teamwork } \\
\text { dalam menjalankan tugas }\end{array}$ & 3 & 4 \\
\hline 1 & Kelengkapan & $\begin{array}{l}\text { Kelengkapan penyajian } \\
\text { buku pedoman mencakup: } \\
\text { (a) kata pengantar, (b) } \\
\text { daftar isi, (c) isi, (d) daftar } \\
\text { pustaka }\end{array}$ & 5 & 5 \\
\hline 2 & & $\begin{array}{l}\text { Sajian materi telah tersaji } \\
\text { secara runtut }\end{array}$ & 4 & 4 \\
\hline 3 & & $\begin{array}{l}\text { Ilustrasi isi memperjelas } \\
\text { dan mempermudah }\end{array}$ & 3 & 4 \\
\hline
\end{tabular}

\begin{tabular}{|c|c|c|c|c|}
\hline & & $\begin{array}{l}\text { pemahaman. (a) mampu } \\
\text { mengungkap makna atau } \\
\text { 4arti dari objek, (b) bentuk } \\
\text { ilustrasi desain } \\
\text { proporsional dan menarik }\end{array}$ & & \\
\hline 1 & $\begin{array}{c}\text { Kesesuaian } \\
\text { dengan }\end{array}$ & $\begin{array}{l}\text { Bahasa yang digunakan } \\
\text { dalam buku pedoman } \\
\text { mudah dipahami oleh } \\
\text { teamwork dan personil } \\
\text { yang terlibat di dalamnya. }\end{array}$ & 4 & 4 \\
\hline 2 & Kebutuhan & $\begin{array}{l}\text { Sesuai dengan } \\
\text { pengembangan emosional } \\
\text { dan motivasi kinerja } \\
\text { teamwork }\end{array}$ & 4 & 4 \\
\hline 1 & & $\begin{array}{l}\text { Bahasa yang digunakan } \\
\text { dalam buku pedoman } \\
\text { sesuai dengan EYD/Ejaan } \\
\text { Yang Disempurnakan }\end{array}$ & 3 & 4 \\
\hline 1 & ㅁ & $\begin{array}{l}\text { Bahasa yang digunakan } \\
\text { dalam buku pedoman } \\
\text { sesuai dengan EYD/Ejaan } \\
\text { Yang Disempurnakan }\end{array}$ & 3 & 4 \\
\hline 2 & & $\begin{array}{l}\text { Sistematika dalam buku } \\
\text { pedoman sesuai dengan } \\
\text { kaidah penulisan buku }\end{array}$ & 4 & 4 \\
\hline
\end{tabular}

\begin{tabular}{llll}
\hline 3 & $\begin{array}{l}\text { Menggunakan bahasa yang } \\
\text { efektif dan efisien }\end{array}$ & 3 & 4 \\
\hline 4 & $\begin{array}{l}\text { Menggunakan bahasa yang } \\
\text { konkret, tidak spekulatif } \\
\text { dan efektif }\end{array}$ & 4 & 4
\end{tabular}

\begin{tabular}{lcc}
\hline Jumlah Nilai & 41 & 45 \\
\hline Jumlah Nilai Maksimal & 55 & 55 \\
\hline Persentase & $75 \%$ & $82 \%$ \\
\hline
\end{tabular}

kita dapat mengetahui bahwa buku pedoman manajemen teamwork MTs. At-Tahririyah Pangpajung Modung Bangkalan pada seluruh komponen kebahasaan hasil skor validasi 1 adalah 41 dengan presentase $75 \%$ yang berarti baik, layak dan perlu direvisi. Validasi II pada validasi materi memperoleh skor 45 dengan presentase $82 \%$ yang berarti buku pedoman manajemen teamwork sudah baik, layak digunakan di MTs. At-Tahririyah Pangpajung Modung Bangkalan dan tidak perlu direvisi.

\section{Keefektifan Buku Pedoman yang Dikembangkan}

\section{Uji Coba}

Untuk menguji efektivitas buku pedoman manajemen teamwork, peneliti menggunakan desain "before-after" yaitu desain penelitian dengan cara membandingkan keadaan sebelum-sesudah perlakuan (Sugiono, 2010) Uji coba dilakukan dengan membandingkan hasil angket $\mathrm{O} 1$ dan $\mathrm{O} 2$. $\mathrm{O} 1$ adalah skor angket sebelum menggunakan buku pedoman sedangkan $\mathrm{O} 2$ adalah skor angket setlah menggunakan buku pedoman. Keefektifan buku pedoman diukur dengan cara membandingkan antara skor $\mathrm{O} 1$ dengan $\mathrm{O} 2$. Sedangkan uji signifikansinya menggunakan Uji-t. Jika nilai signifikansinya $>0,05$; maka tidak ada hubungan antara efektifitas kinerja teamwork sebelum dan sesudah menggunakan buku pedoman akan tetapi jika nilai signifikansinya $<0,05$ maka terdapat hubungan antara efektivitas kinerja teamwork sebelum dan sesudah menggunakan buku pedoman.

\section{Hasil Uji Coba}

Sebelum peneliti menampilkan hasil uji coba buku pedoman, perlu peneliti jelaskan bahwa untuk melakukan uji signifikansi dengan menggunakan Uji-t sampel berpasangan, harus memenuhi syarat yaitu data yang akan diujicobakan harus berdistribusi normal. Untuk dapat mengetahui bahwa data tersebut berdistribusi normal, terlebih dahulu harus melakukan Uji Normalitas. Oleh sebab itu, dalam penelitian ini peneliti melakukan uji normalitas dengan menggunakan Shapiro-Wilk (Sudjana, 2013). Adapun hasil uji normalitas sebagai berikut.

\section{KESIMPULAN}

Berdasarkan hasil penelitian tentang buku pedoman manajemen teamwork, maka dapat 
disimpulkan sebagai bahwa (1) Proses pengembangan buku pedoman manajemen teamwork MTs. At-Tahririyah Pangpajung Modung Bangkalan melalui tiga proses sesuai dengan model pengembangan the Four-D Models yang sudah dimodifkasi peneliti menjadi 3-D, yaitu tahap pendefinisian (define), tahap perancangan (design), dan tahap pengembangan produk (develop), (2) Kualitas buku pedoman manajemen teamwork MTs. AtTahririyah Pangpajung Modung Bangkalan dikembangkan dengan mengunakan 2 kriteria yaitu kevalidan dan keefektifan.

Kualitas buku pedoman manajemen teamwork ditentukan berdasarkan produknya (isi/materi dan kebahasaan), kedua aspek tersebut divalidasi dan dinyatakan valid oleh validator, dengan melihat hasil persentase validasi 1 dan validasi 2 .

Berdasarkan hasil validasi ahli di atas, buku pedoman manajemen teamwork MTs. AtTahririyah Pangpajung Modung Bangkalan pada seluruh komponen validasi materi hasil skor validasi 1 adalah 151 dengan presentase $77 \%$ yang berarti baik, layak dan perlu direvisi. Validasi II pada validasi materi memperoleh skor 179 dengan presentase $72 \%$ yang berarti buku pedoman manajemen teamwork sudah baik, layak digunakan.

Sedangkan hasil validasi seluruh komponen kebahasaan hasil skor validasi 1 adalah 41 dengan presentase $75 \%$ yang berarti baik, layak dan perlu direvisi. Validasi II pada validasi materi memperoleh skor 45 dengan presentase $82 \%$ yang berarti buku pedoman manajemen teamwork sudah baik, layak digunakan di MTs. At-Tahririyah Pangpajung Modung Bangkalan dan tidak perlu direvisi, (3) Keefektivan buku pedoman, berdasarkan hasil uji coba pada 24 responden, dari olahan data pre test dan post tes menggunakan analisis ujit diketahui nilai $r$ sebesar $0,314^{2}=0,56$. Angka ini menunjukkan bahwa penggunanan buku pedoman mempengaruhi efektivitas kinerja teamwork. Besarnya pengaruh tersebut adalah $56 \%$. Sedangkan nilai signifikansinya adalah sebesar 0,00 yang artinya nilai tersebut < 0,05 , sehingga dapat disimpulkan bahwa penggunaan buku pedoman dapat meningkatkan efektivitas kinerja teamwork.

\section{SARAN}

Berdasarkan simpulan dan beberapa temuan pada hasil penelitian, maka peneliti dapat mengemukakan saran sebagai berikut:
(1) Produk buku pedoman manajemen teamwork ini dapat digunakan sebagai panduan untuk melakukan program madrasah/sekolah yang sifatnya dilakukan dengan melibatkan banyak orang, (2) Produk buku pedoman manajemen teamwork ini digunakan untuk menumbuhkan minat serta motivasi kerja teamwork dalam melaksanakan tugas mereka karena isinya memudahkan mereka, (2) Buku pedoman manajemen teamwork ini bisa dijadikan acuan bagi madrasah/sekolah yang ingin meningkatkan manajemennya terutama pada sekolah yang selalu berkomitmen untuk meningkatkan mutu pendidikannya, (4) Buku pedoman ini bisa dijadikan sebagai acuan bagi madrasah/sekolah untuk menata dan mengelola lembaga pendidikan yang lebih baik.

\section{DAFTAR RUJUKAN}

Arikunto, Suharsimi. (1998). Prosedur penelitian suatu A'yuna Qorrie.(2015). Manajemen Teamwork sebagai Implementasi Total Quality Management (TQM) di Pondok Pesantren Modern Darussalam Gontor Putri 3, Fakultas IImu Pendidikan Universitas Negeri Yogyakarta.

Dewi, Sandra, 2007, Teamwork, Bandung. Progressio.

Gaspersz, Vincent, Dr. (2002). Total Quality Manajement, Jakarta: Gramedia. Pustaka Utama.

Gomes, Faustino Cordosa. 1997. Manajemen Sumber Daya Manusia, Jakarta: Andi Offset

Gomes, Foustino Cardoso. 2003. Manajemen Sumber Daya Manusia. Yogyakarta. ANDI.

Gultom, Syawal. 2012. Pedoman Teknis Peningkatan Kompetensi Pamong Belajar melalui Pendidikan dan Pelatihan. Jakarta: Kemendikbud Badan Pengembangan SDM Pendidikan dan Kebudayaan dan Penjaminan Mutu Pendidikan. Pusat Pengembangan Profesi Pendidik.

Hadis, Abdul (1994). Manajemen Mutu Pendidikan, Bandung: Alfabeta. 
Hafiuddin, Didi \& Tanjung Hendri. (2003).Manajemen Syari'ah Dalam Praktik. Jakarta: Gema Insani

Hidayat Arif.(2012). Evaluasi Manajemen Mutu Terpadu (MMT) di SMPN 21 dan 36 Surabaya: Pascasarjana Universitas Negeri Surabaya.

Lestari Puji. (2004).Penerapan Total Quality Management (TQM) di Institut Pengembangan Surabaya:Pascasarjana Universitas Negeri Surabaya.

M. Ridlwan. (2005).Implementasi Total Qualiy Management dalam Sistem Layanan Akademik di Fakultas Keguruan Universitas Muhammadiyah, Surabaya, Thesis, Surabaya. :PPS UNESA

Machali, Imam dan Ara Hidayat. 2015. The Handbook of Education Management. Yogyakarta: Magister Pendidikan Islam Universitas Islam Negeri Sunan Kalijaga.

Muhaimin, Hj. Suti'ah, Sugeng Listyo Prabowo, 2015. Manajemen Pendidikan Aplikasinya dalam Penyusunan Rencana Pengembangan Sekolah/Madrasah. Jakarta, Kencana Predana Media Group.

Nasution, M. N. (2005). Manajemen Mutu Terpadu (Total Quality Management) Jakarta: Ghal.ia Indonesia.

Nurkholis, 2006. Manajemen Berbasis Sekolah, teori, Model dan Aplikasi. Jakarta. Grasindo.

Rahmawati, Kusdyah. 2008. Manajemen Sumber Daya Manusia. Yogyakarta. ANDI.

Riduwan. 2014. Manajemen Pendidikan. Bandung: Alfabeta.

Rivai, V. 2005. Manajemen SDM untuk perusahaan. Jakarta: Rajawali Press

Sallis, Edward. (2006). Total Quality Management (TQM) in Education. Penterjemah Ahmad Ali Riyadi. Yogyakarta: IRCiSoD
Sarno. (2005). Implementasi Nilai-nilai Total Quality Management (TQM) Bidang Pendidikan pada Sekolah-sekolah di bawah Departemen Agama Kota Salatiga, Thesis: Program Pascasarjana Universitas Muhammadiyah Surakarta.

Seputra, Agung. 2014. Manajemen dan Perilaku Organisasi. Yogyakarta. Graha IImu.

Simamora, H. 2006. Manajemen Sumber Daya Manusia Edisi ke 2. Sekolah Tinggi IImu Ekonomi

Sudjana, 2000. Manajemen Program Pendidikan: untuk Pendidikan Luar Sekolah dan Pengembangan Sumber Daya Manusia. Bandung: Falah Production.

Sugiyono. (2016).Metode Penelitian \& Pengembangan, Research and Development, Bandung: Alfabeta.

2015. Metode penelitian dan pengembangan (Research and Development). Bandung: Alfabeta.

2010, Metode Penelitian Pendidikan Pendekatan Kuantitatif, Kualitatif dan $R \& D$, Bandung: Alfabeta.

Sukirno. 2004. Manajemen Sumber Daya Manusia. Edisi kedua. Yogyakarta. ANDI.

Suniwidada. (2013). Pengaruh Total Quality Management (TQM) terhadap Kinerja Karyawan Melalui Budaya Kualitas (Study Kasus pada Fakultas Filsafat Universitas Gajah Mada): Pascasarjana Universitas Muhammadiyah Yogyakarta

Supriyanto, Ahmad \&Zaini Rohmad, 2002, Pengembangan \& Implementasi TQM pada Sistem Layanan Akademik, Jurnal Pendidikan, 9 (1) 69-82.

Syafaruddin.(2002).Manajemen Mutu Terpadu dalam Pendidikan, Jakarta: Grasindo.

Thiagarajan, S Semmel, D.S \& Semmel, M.I, Instructional Development for Training Teacher of Expectional Children.Minneapolis, Minnesota: 
Leadership Training Institute/Special Education:University Minnesota

Tim Pengembang IImu Pendidikan (2007). IImu Aplikasi Pendidikan.Bandung:IMTIMA.

Tjiptono Fandi \& Diana Anastasia.(2003). Total Quality Management (TQM) edisi revisi. Yogyakarta: Andi Offset

Tracy, Brian, 2006. Pemimpin Sukses, Penerjemah Suharsono dan Ana Budi Kuswandani, Jakarta. Pustaka Delapatrasa.

Wibowo, 2015. Perilaku dalam Organisasi, Jakarta. Rajawali Pers

Winardi, J. 2014. Manajemen Perilaku Organisasi. Jakarta. Prenada Media Group.

Yun Iswanto. (2002).Manajemen Sumber Daya Manusia, Jakarta: BPK-Pustaka Penerbitan UT. 